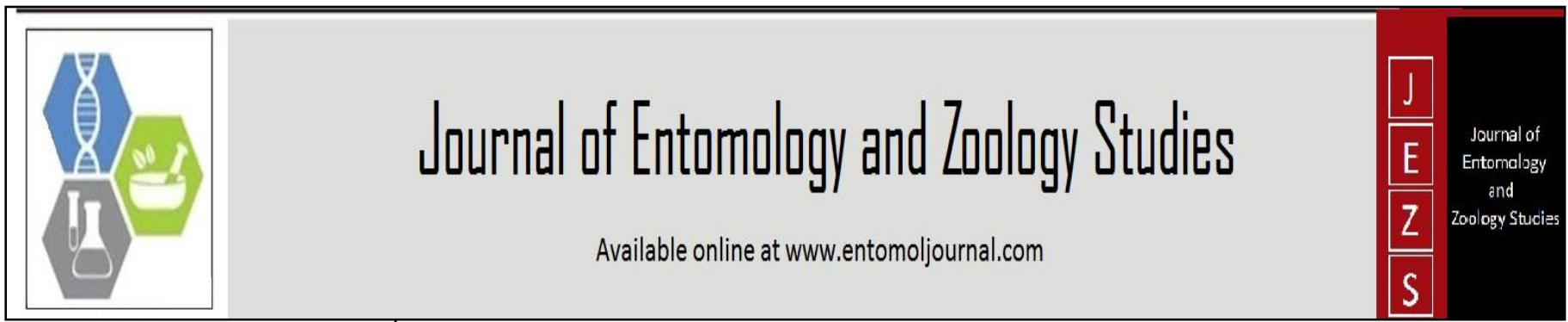

E-ISSN: 2320-7078

P-ISSN: 2349-6800

www.entomoljournal.com JEZS 2021; 9(2): 1419-1422 (C) 2021 JEZS

Received: 22-01-2021

Accepted: 24-02-2021

Sunil M Gaikwad

Department of Zoology,

Shivaji University, Kolhapur,

Maharashtra, India
Corresponding Author: Sunil M Gaikwad

Department of Zoology,

Shivaji University, Kolhapur,

Maharashtra, India

\section{First report of Spodoptera eridania (Stoll) (Lepidoptera: Noctuidae) on soybean [Glycine $\max ($ L.) Merrill] from Kolhapur, Maharashtra, India}

\section{Sunil M Gaikwad}

DOI: $\underline{\text { https://doi.org/10.22271/j.ento.2021.v9.i2q.8664 }}$

\section{Abstract}

The Southern armyworm Spodoptera eridania (Stoll) (Lepidoptera: Noctuidae) is a polyphagous defoliator having a wide host range including Soybean. They are one of the important defoliators in the tropical and subtropical regions of the hemisphere. However, this pest is reported for the first time from Kolhapur, Maharashtra, India on Soybean [Glycine max (L.) Merill].

Keywords: soybean, southern armyworm Spodoptera eridania, India

\section{Introduction}

Spodoptera is a genus of the Noctuidae family of moths, which was erected by Guenée in 1852. The larvae are called armyworm and most of them are pests on the crop. Approximately 30 species of this genus are distributed across six continents ${ }^{[1,2]}$. A study of the literature on species of genus Spodoptera reveals that 3 species of it have been found in India so far, namely Spodoptera frugiperda ${ }^{[3]}$, Spodoptera exigua ${ }^{[4]}$ and Spodoptera litura ${ }^{[5]}$ as a pest of various crops including Soybean.

Soybean [Glycine max (L.) Merrill] is one of the most important oilseed crops in the world and due to its multi-dimensional uses it is known as 'Golden Bean' or 'Miracle Bean'. In India, considering the prevalence of Spodoptera on soybean, it is found that so far only S. litura, a defoliator species, has been attacked and the crop has been damaged [6, 7, 8, 9]. The southern armyworm Spodoptera eridania which has not yet been recorded in India is found mainly in North America, South America through the Caribbean and Central America. They are the most important defoliators in the tropical and subtropical regions of the Western Hemisphere, which feed the plants in large quantities when they are young, resulting in often skeleton leaves of the host plants ${ }^{[10]}$. For the first time in India, S. eridania is being recorded at village Tamgaon $\left(16^{\circ} 39^{\prime} 14.0^{\prime \prime} \mathrm{N}, 7^{\circ} 18^{\prime} 23.4^{\prime \prime E}\right)$, Kolhapur, Maharashtra, India (Fig. 1) on soybean crop through this article.

\section{Material and Methods}

The sowing of Soybean seed (Mahabeej JS-335 variety) was done on June 24, 2019, at Tamgaon (Fig.1) and observations were made up to the harvest of the crop. The identification of late instar larvae was done with the help of recent literature Passoa [11], Capinera [12], OEPP/EPPO ${ }^{[13]}$ and caterpillar photographs at the website of CABI ${ }^{[14]}$. In the laboratory, attempts were made to obtain their adults by rearing $S$. eridania larvae but could not succeed.

\section{Results and Discussion}

While inspecting the soybean crop in my field initially in June and July it was healthy (Fig.2a) but during Sep. 2019, it was noticed that soybean seedlings have turned white in some places (Fig.2b). After careful observation, it was noticed that the crop was infested with larvae and so the soybean leaves were completely skeletonized (Fig.2c). The incidence of such a pest has never been seen before, so curiosity was created about this soybean pest. Meanwhile, while inspecting other soybean fields in my village, it was found that other fields have suffered 
similar damage. Upon closer inspection, it was found that caterpillars, other than S. litura, were hiding near soybean pods and eating pods (Fig.2d). Photographs of the larvae were taken and their characters were examined, and it was concluded that the larvae were $S$. eridania, which had not yet been found on any crop in India. The larvae were identified from Passoa ${ }^{[11]}$, Capinera ${ }^{[12]}$, OEPP/EPPO ${ }^{[13]}$ and caterpillar photographs at the website of CABI ${ }^{[14]}$.

The $S$. eridania is native to the American tropics found in the South Eastern United States from Maryland South to Florida and to the west in Kentucky and Texas; in the Neotropics, it is from Mexico to the whole of the Caribbean and South through Central America to Argentina ${ }^{[13]}$. They attack heavily on crops while they are young, often resulting in skeleton leaves on their food plants. As they mature, they become solitary and also bore readily into fruit, often damaging tomato in Florida [12]. The observation in the present study is following the observation of Capinera ${ }^{[12]}$ in which $S$. eridania has done so much damage by eating whole soybean leaves and making soybean leaves skeletonize and its late instar larvae have been found to remain solitary and eat soybean pods.

According to OEPP/EPPO [13], the late instar larva of $S$. eridania shows a strong resemblance to the larva of $S$. littoralis and $S$. litura. The abdominal segments are with large dark dorsal patches are present on abdominal segments (1-8) and smaller patch on thoracic segments while other abdominal segments dark but smaller dorsal patches present. The late instar form of $S$. eridania of the present study shows a prominent dark lateral spot on the first abdominal segment, which passes through the spiracular line which is not pronounced as in S. litura. The characters and position of the lateral spot are following the observations made by Passoa [11] who reported that the spot in the larva of $S$. eridania obscures the spiracular line on and sometimes in front of the first abdominal segment. He also stated that $S$. eridania can be recognized from different species on the grounds that in different species this lateral spot doesn't go through the spiracular line. If the origin is America, the most steady character that distinguishes $S$. eridania, is the presence of large dorsal marking on abdominal segment 1 which is bigger than the ones, if present, on segments $2-7^{[13]}$. Although $S$. eridania in the present study is found in India, the characters in it match the observations reported by OEPP/EPPO ${ }^{[13]}$. According to the District Disaster Management Cell, the Kolhapur district receives an average rainfall of 1,772 mm between June 1 and September 30. However, the average rainfall till September 19, 2019 was 2,584 mm, breaking the record of the last ten years. The Karveer taluka, which includes Tamgaon, a present locality of $S$. eridania, received double the average rainfall in the year 2019. An outbreak of $S$. eridania may have been found on soybeans due to this excess rainfall.

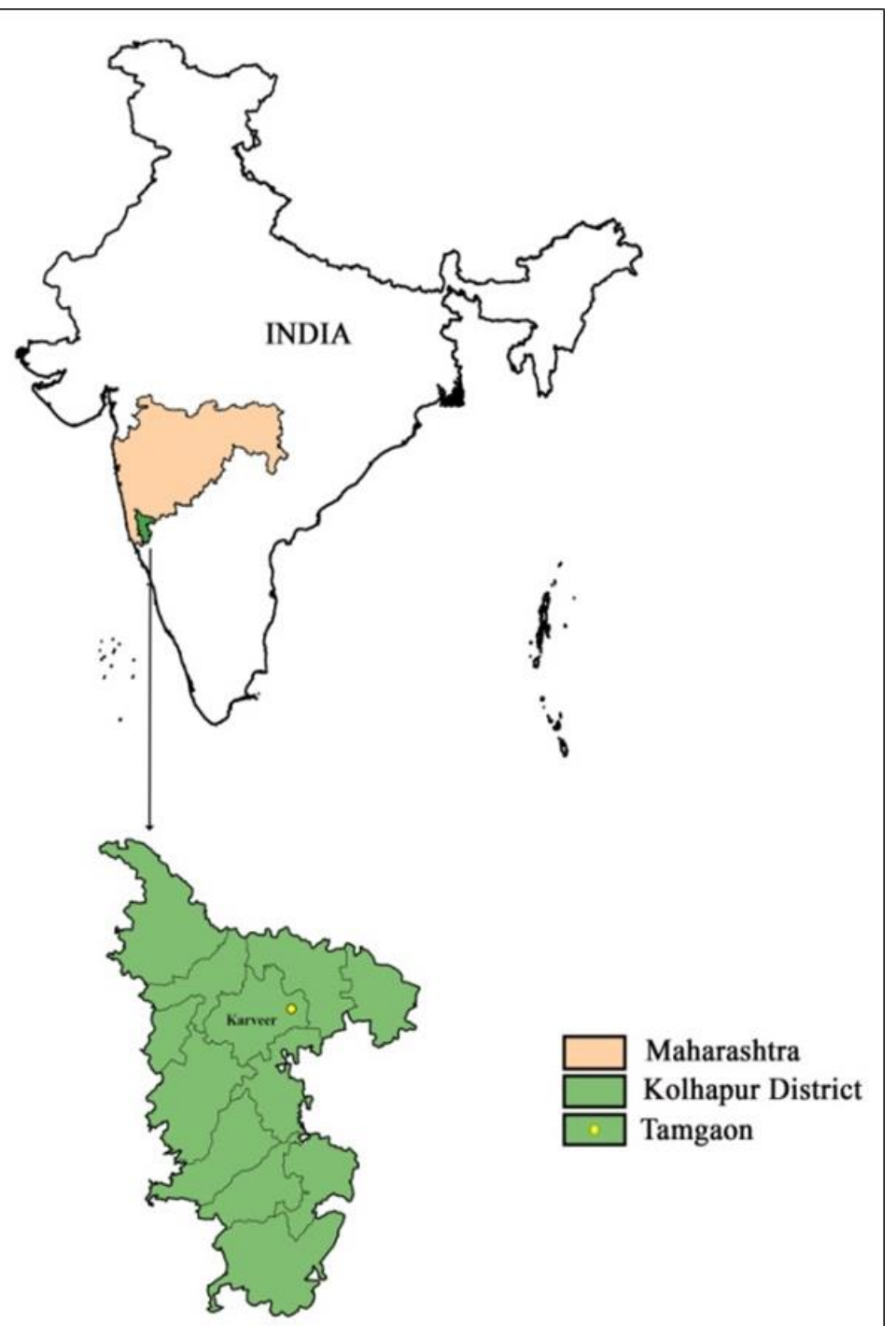

Fig 1: Map showing locality (Tamgaon) of Spodoptera eridania 


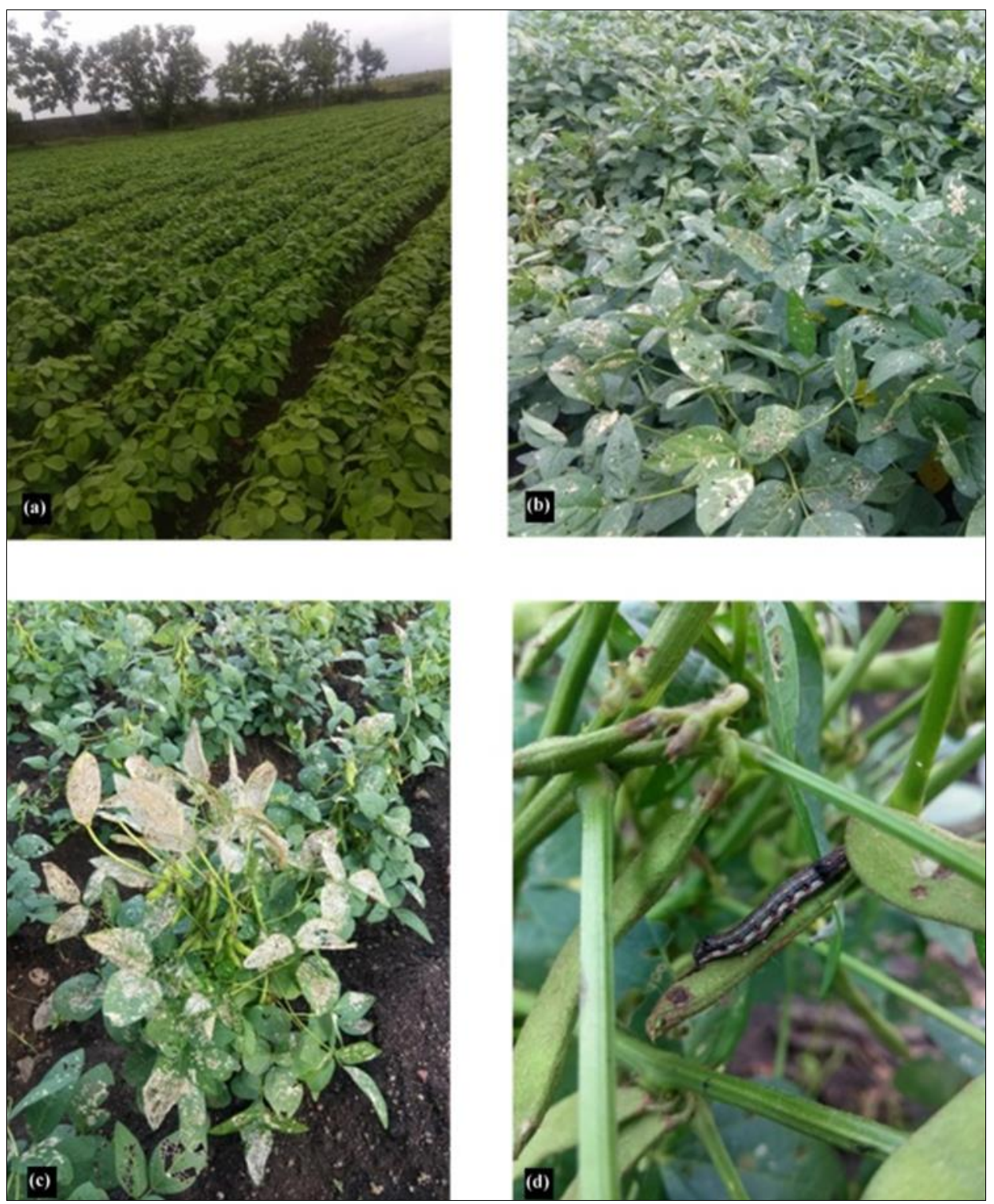

Fig 2: Healthy crop of soyabean in last week of July (a). Skeletonisation of soyabean leaves by attack of S. eridania (B). damage to the soyabean foliage by $S$. eridania larvae (C). and late in star larva of S. eridania feeding on soyabean pods (E).

\section{Conclusion}

The larvae found during the present study are S. eridania which is being reported on soybean for the first time from India. This leads to the conclusion that $S$. eridania is now invaded in India and needs to be addressed soon.

\section{Acknowledgements}

The author is thankful to the Head, Department of Zoology, Shivaji University, Kolhapur (India) for providing a laboratory facility.

\section{References}

1. Meagher RL, Brambila J, Hung E. Monitoring for exotic Spodoptera species (Lepidoptera: Noctuidae) in Florida. Florida Entomologist 2008;91(4):517-522.

2. Nagoshi RN, Brambila J, Meagher RL. Use of DNA barcodes to identify invasive armyworm Spodoptera species in Florida. Journal of Insect Science 2011;11:154. (Accessed 14 April 2021).

3. Sharanabasappa, Kalleshwaraswamy CM, Asokan R, Mahadeva Swamv HM, Marutid MS, Pavithra HB et al. First report of the Fall armyworm, Spodoptera frugiperda
(J E Smith) (Lepidoptera: Noctuidae), an alien invasive pest on maize in India. Pest Management in Horticultural Ecosystem 2008;24(1):23-29.

4. Pathan NP, Borad PK, Bharpoda TM, Thumar RK. First ever report of beet armyworm, Spodoptera exigua Hubner (Noctuidae: Lepidoptera) on okra (Abelmoschus esculentus L. Moench) from Gujarat, India. Journal of Entomology and Zoology Studies 2018;6(4):1919-1921.

5. Fand BB, Sul NT, Bal SK, Minhas PS. Temperature Impacts the Development and Survival of Common Cutworm (Spodoptera litura): Simulation and Visualization of Potential Population Growth in India under Warmer Temperatures through Life Cycle Modelling and Spatial Mapping. PLoS ONE 2015;10(4):e0124682. doi:10.1371/journal.pone.0124682

6. Pawar AD. Integrated Pest Management package for Soybean. Government of India, Ministry of Agriculture and Cooperation. Directorate of Plant Protection, Quarantine and Storage, Faridabad 2001, 24.

7. Sharma AN, Gupta GK, Verma RK, Sharma OP, Bhagat $\mathrm{S}$, Amaresan $\mathrm{N}$ et al. Integrated Pest Management Package for Soyabean. ICAR-National Center for 
Integrated Pest Management 2014, 41.

8. Suyal P, Gaur N, Rukesh Pramod KN, Devrani A. Seasonal incidence of insect pests and their natural enemies on soybean crop. Journal of Entomology and Zoology Studies 2018;6(4):1237-1240.

9. Sable GS, More DG, Munemanik RM, Wahekar GR. Seasonal incidence of pests of soybean (Glycine max (L.) Merrill influenced by different sowing dates. Journal of Entomology and Zoology Studies 2018;6(6):778-781.

10. Spodoptera eridania. https://en.wikipedia.org/wiki/Spodoptera_eridania (Accessed on April 9, 2021).

11. Passoa S. Color identification of economically important Spodoptera larvae in Honduras (Lepidoptera: Noctuidae). Insecta Mundi 1991;5(3-4):185-196.

12. Capinera JL. Southern armyworm, Spodoptera eridania (Stoll) (Insecta: Lepidoptera; Noctuidae). Featured Creatures. University of Florida 1999;EENY-0106:1-4.

13. OEPP/EPPO. PM 7/124 (1) Spodoptera littoralis, Spodoptera litura, Spodoptera frugiperda, Spodoptera eridania. European and Mediterranean Plant Protection Organization 2015;45(3):410-444.

14. CABI. Invasive Species Compendium Datasheet Spodoptera eridania (southern armyworm). 2020. https://www.cabi.org/isc/datasheet/44518 (Accessed on April 15, 2021). 